\title{
ADITIVOS EM SILAGEM DE CAPIM ELEFANTE PARAÍSO (PENNISETUM HYBRIDUM CV. PARAÍSO)
}

\author{
ADDITIVES IN SILAGE OF PARAISOGRASS (PENNISETUM HYBRIDUM CV. PARAISO)
}

\author{
Ferrari Junior, E. ${ }^{1 \mathrm{~A}}$, V.T. Paulino ${ }^{1 \mathrm{~B}}$, R.A. Possenti ${ }^{1 \mathrm{C}}$ e T.L. Lucenas ${ }^{1}$
}

${ }^{1}$ Instituto de Zootecnia. APTA/SAA. Caixa Postal 60. CEP 13460-000. Nova Odessa/SP. Brasil. Aferrari@iz.sp.gov.br; Bpaulino@iz.sp.gov.br; 'cpossenti@iz.sp.gov.br

\section{PalaVRas ChaVE ADICIONAIS}

Ácidos orgânicos. Aditivo comercial. Composição química. Óxido de cálcio. Polpa cítrica.

\section{RESUMO}

No Instituto de Zootecnia, Nova Odessa, Brasil, estudou-se o capim Pennisetum hybridum cv. Paraíso, com vistas ao processo de ensilagem. Aos 100 dias de idade, foi cortado e ensilado conforme os seguintes tratamentos: 1) capim paraíso (CP) sem aditivo, 2) $\mathrm{CP}+5 \%$ de polpa cítrica, 3) $\mathrm{CP}+10 \%$ de adição de polpa cítrica, 4$)$ $\mathrm{CP}+1 \%$ de óxido de cálcio e 5) $\mathrm{CP}+$ aditivo comercial (Silomax), em delineamento em blocos ao acaso (5 tratamentos $\times 4$ repetições). As porcentagens de MS, PB, DIVMS e ácido lático aumentaram com a adição de polpa cítrica. A FDN e FDA decresceram para este mesmo aditivo. A adição de óxido de cálcio não favoreceu a qualidade da silagem. O aditivo comercial (Silomax) controlou a fermentação indesejável, com exceção do tratamento com óxido de cálcio, os outros tratamentos apresentaram características nutricionais e fermentativas adequadas ao processo de ensilagem para o capim paraíso.

\section{SUMMARY}

This experiment was conducted at Instituto de Zootecnia, Nova Odessa, Brazil, in order to evaluate the silage Pennisetum hybridum cv. Paraisograss, with 100 days old. The treatments of the ensiled grass studied were: 1) Pennisetum hybridum cv. Paraíso (PG) without additive, 2) PG $+5 \%$ of citric pulp, 3) PG + with $10 \%$ of citric pulp, 4) $\mathrm{PG}+$ with $1 \%$ of calcium oxide and 5) PG + commercial additive (Silomax). The experimental design employed was randomised blocks (5

Recibido: 4-7-07. Aceptado: 1-10-07.

\section{AdDitional KEYWORDS}

Calcium oxide. Citric pulp. Comercial additive. Chemical composition. Organic acids.

treatments vs. 4 replications). DM, CP, IVDM digestibility and lactic acid contents increased with citric pulp addition. NDF and ADF decreased for this same additive. Calcium oxide addition did not affect the fermentative characteristics of silage. The commercial additive controlled the non desirable fermentation and approving the desirable one. Exception the treatment with calcium oxide, the other treatments showed nutrititional and fermentative characterists adequate of ensiling process to Pennisetum hybridum cv. Paraíso.

\section{INTRODUÇÃO}

Na região sudeste do Brasil, vivenciamse características climáticas de crescimento estacional das plantas forrageiras, alto custo da terra e exploração pecuária bastante desenvolvida. Face a esta realidade, processos de conservação de forragens desempenham importante papel no sentido de eliminar defasagens na disponibilidade de alimentos, permitindo assim, uma produção de carne e leite equilibrada durante o ano.

O processo de ensilagem envolve a conversão de carboidratos solúveis em ácido lático, que provocam queda no $\mathrm{pH}$ da massa ensilada a níveis que inibem a atividade microbiana, preservando suas características.

Arch. Zootec. 58 (222): 185-194. 2009. 


\section{FERRARI JUNIOR, PAULINO, POSSENTI E LUCENAS}

Visto que os capins do gênero Pennisetum apresentam elevada produção de massa verde por hectare durante o período das chuvas (outubro a março), a ensilagem constitui um dos principais métodos de conservação dessa gramínea.

Em passado recente, foi lançado no mercado, híbrido de capim elefante (Pennisetum purpureum, Schum.) com milheto (Pennisetum glaucum, (L) R.Br), denominado de capim elefante paraíso (Pennisetum hybridum cv. Paraíso), que possui a vantagem de ser plantado e multiplicado por sementes, diferentemente das demais variedades que são multiplicadas por meio de mudas. Este cruzamento associou a qualidade do milheto com o potencial de alta produção de matéria seca do capim elefante.

Contudo, em fase de desenvolvimento quando a produção e o valor nutritivo são adequados aos diversos cultivares de capim elefante, o excesso de umidade presente ( $80 \%$ ou mais) aumentam o risco de fermentação indesejável com maior produção de ácidos acético e butírico, de nitrogênio amoniacal, amidas e aminas (Schank et al., 1992).

Sendo assim, a composição química e o valor nutritivo das silagens podem ser modificados por meio da utilização de aditivos no momento da ensilagem, os quais, podem ser compostos por ácidos, sais, carboidratos fermentáveis ou culturas de bactécias láticas, além de enzimas.

Os aditivos têm dois principais propósitos na silagem: influenciar o processo fermentativo favorecendo a conservação e melhorar o valor nutritivo. Outros propósitos como a diminuição de perdas superficiais e na camada exposta da silagem, aumento da vida útil, aumento do valor energético, melhora da digestibilidade da fibra e da matéria seca e melhora no desempenho animal, também são observados em silagem com o uso de aditivos bacterianos (Keplin, 2006).

Segundo Bergamaschine et al. (2006), o ingrediente usado como aditivo nas silagens de capim deve apresentar alto teor de matéria seca, alta capacidade de retenção de água, boa palatabilidade, além de fornecer carboidratos para fermentação. Como também ser de fácil manipulação, baixo custo e fácil aquisição.

Por outro lado, aditivos inoculantes apresentam em sua formulação uma associação de bactérias láticas e enzimas derivadas de subprodutos microbianos. Microrganismos como os dos gêneros Bacillus e Aspergillus produzem celulases, hemicelulases, amilases, glicoamilases e proteases que podem promover a digestão de carboidratos estruturais e não estruturais como no caso do amido, produzindo açúcares solúveis utilizados como substrato para a fermentação lática (Patrizi et al., 2004).

A polpa cítrica é um subproduto da agroindústria bastante utilizada como aditivo em silagens por apresentar cerca de $6-8 \%$ de proteína bruta e teor energético alto, ou seja, da ordem de $78 \%$ de nutrientes digestíveis totais. Com relação à quantidade, embora haja efeitos positivos com adição de até $30 \%$ em peso, os melhores resultados são obtidos com níveis entre 4 e $15 \%$, que devem ser misturados ao capim elefante no momento da ensilagem (Bergamaschine et al., 2006). É considerada um dos mais refinados e nutritivos subprodutos da agroindústria para bovinos, entretanto, as restrições ao uso ficam por conta do preço, que oscila em função do mercado externo (Evangelista etal., 2001).

Outros produtos como a cal virgem micropulverizada ou óxido de cálcio podem ser utilizados. Este produto tem sido utilizado para reduzir a fermentação alcoólica em silagens de cana-de-açúcar, solubilizando parcialmente a hemicelulose, promovendo o fenômeno conhecido como entumescimento alcalino da celulose, que consiste na expansão das moléculas de celulose, causando a ruptura das ligações da pontes de hidrogênio aumentando a digestão da celulose e da hemicelulose (Oliveira et al., 2007). Balieiro Neto e Lima(2006) observaram 
que a adição de $1 \%$ de óxido de cálcio na cana picada para a confecção da silagem reduziu os constituintes da parede celular por hidrólise alcalina e promoveu maior recuperação de matéria seca $(83,18$ para $92,75 \%$ ) no pós-abertura, além disso contribuiu para preservação de nutrientes solúveis, provavelmente por inibir o desenvolvimento de leveduras que atuam sobre a massa ensilada, amenizando a perda de valor nutritivo durante a ensilagem e após a abertura do silo. Houve melhor preservação e estabilidade da massa ensilada no pós-abertura (36 para 134 horas) e aumento da digestibilidade verdadeira da matéria seca (62 para 70\%).

Diante do exposto, procurou-se neste trabalho avaliar a qualidade e o valor nutritivo da silagem de capim elefante paraíso, com e sem a presença de aditivos bacterianos comerciais, com polpa cítrica e com óxido de cálcio.

\section{MATERIALE MÉTODOS}

O experimento foi conduzido no Centro de Pesquisa e Desenvolvimento em Nutrição Animal e Pastagens (CPDNAP), do Instituto de Zootecnia, localizado no município de Nova Odessa, São Paulo, Brasil.

Os valores de precipitação total durante o período experimental foram de $657 \mathrm{~mm}$.

O experimento foi conduzido num solo classificado como Podzólico distrófico, o qual apresentava as seguintes características químicas: $\mathrm{pH}=3,7 ; \mathrm{M} . \mathrm{O} .=28 \mathrm{~g} / \mathrm{dm}^{3} ; \mathrm{Ca}$ $+\mathrm{Mg}=2 \mathrm{mmolc} / \mathrm{dm}^{3} ; \mathrm{K}=2,6 \mathrm{mmolc} / \mathrm{dm}^{3} . \mathrm{P}=$ $5 \mathrm{mg} / \mathrm{dm}^{3} ; \mathrm{Al}=16 \mathrm{mmolc} / \mathrm{dm}^{3} \mathrm{e} \mathrm{V}=6 \%$. Foi feita a correção do solo com calcário dolomítico, na quantidade de 4,5 t/ha, para elevar o índice de saturação por bases a $60 \%$.

O sulcamento do solo foi feito com espaçamento de $0,60 \mathrm{~m}$ entre linhas e profundidade de plantio de 1,0 a $2,0 \mathrm{~cm}$, com densidade de sementes de $12 \mathrm{~kg} / \mathrm{ha}$. Como adubação de plantio, utilizaram-se $80 \mathrm{~kg}$ de $\mathrm{P}_{2} \mathrm{O}_{5}$ por hectare e decorridos 45 dias, efetuou-se cobertura com $80 \mathrm{~kg}$ de $\mathrm{N}$ e 120 $\mathrm{kg}$ de $\mathrm{K}_{2} \mathrm{O} / \mathrm{ha}$, através dos adubos superfosfato simples, sulfato de amônio e cloreto de potássio, respectivamente.

Para confecção das silagens experimentais, o corte do capim elefante paraíso foi efetuado aos 100 dias de crescimento, através de corte com segadeira tracionada por trator a uma altura da superfície solo de $10 \mathrm{~cm}$ e imediatamente colhida e transportada para trituração em ensiladeira regulada para cortes de $1,0 \mathrm{~cm}$. de comprimento. Como silos foram utilizados baldes plásticos com capacidade de aproximadamente $15 \mathrm{~kg}$ de material verde picado, correspondendo a uma compactação de aproximadamente 460 $\mathrm{kg}$ de silagem $/ \mathrm{m}^{3}$.

Foram avaliados 5 tratamentos dispostos em blocos ao acaso com 4 repetições: T1: silagem de capim elefante Paraíso; T2: silagem de capim elefante Paraíso $+5 \%$ de polpa cítrica; T3: silagem de capim elefante Paraíso $+10 \%$ polpa cítrica; T4: silagem de capim elefante Paraíso $+1 \%$ óxido de cálcio e T5: silagem de capim elefante Paraíso + aditivo comercial (Silomax: Lactobacillus plantarum 2,5 x $10^{10}$ u.f.c./g e Pediococcus pentosaceus $2,5 \times 10^{10}$ u.f.c./g).

A incorporação dos aditivos ao material picado foi efetuada à medida que se processava cada tratamento.

Decorridos 90 dias de armazenamento, os silos foram abertos e tomadas amostras das quais extraiu-se, através de uma prensa hidráulica $\left(2 \mathrm{kgf} / \mathrm{cm}^{3}\right)$ o suco das silagens para determinações de: $\mathrm{pH}$, nitrogênio amoniacal conforme procedimentos descritos por Fenner (1965). As determinações dos ácidos orgânicos foram realizadas em cromatografia gasosa, segundo método preconizado por Erwin et al. (1961), nos laboratórios de Bromatologia da Faculdade de Medicina Veterinária/USP/Campus Pirassununga.

No laboratório, as amostras foram présecadas em estufa com circulação de ar forçada a $55^{\circ} \mathrm{C}$ por 72 horas e moídas em moinho tipo Willey, com peneira contendo 
crivos de $1 \mathrm{~mm}$, segundo Silva e Queiroz (2002). Os conteúdos de matéria seca (MS), matéria mineral (MM), extrato etéreo (EE), proteína bruta $(\mathrm{PB})$, nitrogênio em FDN (NIDN) e FDA (NIDA) determinados de acordo com a A.O.A.C. (1995) e as análises de fibra em detergente neutro (FDN), fibra em detergente ácido (FDA), celulose e lignina foram analisadas segundo o método de Goering e Van Soest (1970) e a digestibilidade in vitro da matéria seca (DIVMS) de acordo com Tilley e Terry (1963).

Os resultados foram analisados através do programa computacional Statistical Analysis System (SAS, 1998). Os dados foram submetidos à análise de variância através do PROC GLM (General Linear Models). O modelo estatístico separou como causa de variação o efeito de tratamento. Foi utilizado o nível de significância de 5\% para o teste realizado.

\section{RESULTADOSEDISCUSSÃO}

Observa-se na tabela I, que os teores de matéria seca (MS) não se coadunam com os valores sugeridos por Silveira et al. (1979), de 30 a $35 \%$ de MS para que se obtenha uma boa conservação da forragem. Ressalta-se que o baixo teor de matéria seca do capim Paraíso está relacionado com os elevados índices de precipitação observados no período de avaliação $(657 \mathrm{~mm})$. Verificou-se, no entanto, que ocorreram diferenças $(p<0,05)$ entre os tratamentos, onde a adição de polpa cítrica mostrou efeito positivo sobre este parâmetro estudado.

É de amplo conhecimento o alto valor nutritivo do capim elefante em estádio de crescimento. Nesta condição, seu teor elevado de umidade, dificulta a obtenção de silagens de boa qualidade. A polpa cítrica revelou efetividade em aumentar o teor de MS da forragem ensilada, quando comparada aos outros tratamentos. Entretanto, os valores obtidos com adição de polpa cítrica são inferiores a $25 \%$ sugerido por Haigh (1999) para a mínima formação de efluente e inferior a 30\% preconizado por Silveira et al. (1979) para limitar o crescimento de bactérias do gênero Clostridium. A utilização de aditivos com elevado teor de MS tem sido boa opção para reduzir o teor de umidade do capim elefante no momento da ensilagem. Desta forma, trabalhos desenvolvidos por Bergamaschine et al. (2006) utilizando polpa cítrica, corroboram com os resultados obtidos neste trabalho, mostrando sua eficiência no aumento do teor de MS da silagem de capim Paraiso, em 4,37 e 7,71 pontos percentuais, mediante adição de 5 e $10 \%$ de polpa cítrica, respectivamente.

Os tratamentos sem adição de polpa cítrica mostraram conteúdos de MS próximos aos verificados por Schank et al. (1992), Valadares Filho et al. (2002) e Figueiredo et al. (2004). Estes baixos conteúdos de MS propiciam a proliferação de bactérias do gênero Clostridium conseqüentemente fermentações indesejáveis, com a produção de ácido butírico e degradação de proteínas. Além disso haverá maior lixiviação de nutrientes solúveis.

Os teores de proteína bruta (PB) obtidos nos tratamentos avaliados mostraram-se diferentes $(p<0,05)$,sendo o menor valor verificado para a silagem de capim elefante acrescida de óxido de cálcio (tabela I). O tratamento com óxido de cálcio provocou efeito de tamponamento, inibindo a rápida queda de $\mathrm{pH}$ no material ensilado que associado ao baixo teor de MS, favoreceu o desenvolvimento de microrganismos do gênero Clostridium, pois os mesmos tem sua máxima eficiência em ambientes com elevada atividade de água, elevado $\mathrm{pH}$ e alta temperatura. Segundo Oshima e McDonald (1978), a conversão de ácido lático para butírico, e, a degradação protéica com formação de amônia, gás carbônico e aminas pode ocorrer devido ao excesso de umidade da forragem, não permitindo com isso um $\mathrm{pH}$ estável.

Cabe ressaltar ainda que ocorreu efeito de diluição nos tratamentos com polpa cítrica, pois os teores de PB verificados nestas 
Tabela I. Teores médios (\%) de matéria seca $(M S)$, proteína bruta $(P B)$, extrato etéreo $(E E)$ e matéria mineral(MM) das silagens de capim Pennisetum hybridum cv. Paraíso. (Contents (\%) of dry matter (MS) and crude protein (PB), fat extract (EE) and ash (MM) of Pennisetum hybridum cv. Paraíso silage).

\begin{tabular}{lcccc}
\hline Tratamentos & MS & PB & EE & MM \\
\hline Silagem de capim Paraíso & $17,22^{\mathrm{c}}$ & $14,73^{\mathrm{a}}$ & $2,81^{\mathrm{a}}$ & $6,99^{\mathrm{cd}}$ \\
Silagem de capim Paraíso + 5\% de polpa cítrica & $21,59^{\mathrm{b}}$ & $13,21^{\mathrm{bc}}$ & $2,39^{\mathrm{abc}}$ & $7,81^{\mathrm{b}}$ \\
Silagem de capim Paraíso + $10 \%$ de polpa cítrica & $24,93^{\mathrm{a}}$ & $12,69^{\mathrm{c}}$ & $2,35^{\mathrm{bc}}$ & $7,60^{\mathrm{bc}}$ \\
Silagem de capim Paraíso + CaO & $17,81^{\mathrm{c}}$ & $9,39^{\mathrm{d}}$ & $2,03^{\mathrm{c}}$ & $14,20^{\mathrm{a}}$ \\
Silagem de capim Paraíso + aditivo comercial & $18,56^{\mathrm{c}}$ & $14,14^{\mathrm{ab}}$ & $2,57^{\mathrm{ab}}$ & $6,92^{\mathrm{d}}$ \\
& & & & \\
\hline
\end{tabular}

Médias seguidas de mesma letra na coluna não diferem entre si pelo teste de Tukey a $5 \%$.

silagens foram menores que nos tratamentos sem aditivo e com aditivo comercial, embora não tenha sido verificada diferença significativa $(\mathrm{p}>0,05)$ entre aqueles que receberam $5 \%$ de polpa cítrica e os adicionados de aditivo comercial. Ferrari Junior e Lavezzo (2001) verificaram que o uso de aditivos com objetivo de absorver o excesso de umidade da forragem, proporciona queda no valor nutritivo da mistura, geralmente das frações protéica e fibrosa. De modo geral os teores de PB nas silagens podem ser considerados elevados quando comparados aos de Figueiredo et al. (2004), Patrizi et al. (2004) e Faria et al. (2007) que trabalharam com silagens de Pennisetum purpureum, capim elefante.

Para extrato etéreo (tabela I), os resultados mostraram-se próximos, embora tenha sido verificada diferenças $(p<0,05)$ entre tratamentos.

Com relação à variável matéria mineral (MM), o tratamento com óxido de cálcio apresentou valores superiores $(\mathrm{p}<0,05)$ aos obtidos nos demais tratamentos. Tal fato relaciona-se com a composição química do óxido de cálcio, que entre outros minerais contem $94,1 \%$ de $\mathrm{CaO}$.

Comparando os teores de MM das silagens estudadas, com os dados disponíveis na literatura sobre silagem de capim elefante, verificou-se que estes foram próximos aos verificados por Figueiredo et al.
(2004) e Bergamaschine et al. (2006), que variaram de 6,56 e 7,56\%, respectivamente.

A fração fibra em detergente neutro $($ FDN) foi menor $(p<0,05)$ nos tratamentos com polpa cítrica. Observou-se também decréscimo para o tratamento com óxido de cálcio (tabela II). Depreende-se pelos dados obtidos que a polpa cítrica foi mais eficiente em reduzir essa fração que contém componentes mais indigestíveis. Estes resultados são atribuídos ao menor teor de fibra da polpa cítrica em relação ao capim elefante, ocorrendo portanto, diluição da fração fibrosa da silagem como um todo. Essa alegação encontra respaldo nos trabalhos de Bergamaschine et al. (2006) e Faria et al. (2007) que também relacionam este efeito de diluição aos baixos teores de FDN da polpa cítrica.

Para o tratamento com óxido de cálcio, o decréscimo da fração fibrosa em relação à silagem sem aditivo, pode ser atribuído à hidrólise alcalina dos constituintes da parede celular, fato este, citado por Balieiro e Lima (2006) em trabalho desenvolvido com o mesmo produto em silagem de cana-deaçúcar.

No tocante à fibra em detergente ácido (FDA), houve efeito $(\mathrm{p}<0,05)$ para os aditivos estudados de forma semelhante ao ocorrido com a FDN (tabela II). O menor valor obtido para a silagem com $10 \%$ de polpa cítrica neste trabalho, foi próximo ao 


\section{FERRARI JUNIOR, PAULINO, POSSENTI E LUCENAS}

registrado por Bergamaschine et al. (2006), que foi de $39,45 \%$ para silagem acrescida com a mesma quantidade de polpa cítrica.

Os teores de nitrogênio insolúvel em detergente neutro (NIDN), foram influenciados pelos tratamentos $(\mathrm{p}<0,05)$ conforme tabela II. De forma semelhante ao verificado neste estudo, Reis et al. (2004) também observaram para silagem de capim marandu aumento nos teores de NIDN com adição de $10 \%$ de polpa cítrica, evidenciando que tal efeito deveria estar relacionado a processamento industrial de peletização da polpa (casca, sementes e polpa) os quais sofrem prensagens e posterior secagem a alta temperatura.

Para o tratamento com óxido de cálcio, os valores determinados estariam relacionados à ocorrência de fermentações indesejáveis relacionadas ao crescimento de clostrídios que é estimulado pela alta temperatura de estocagem, baixos teores de matéria seca e carboidratos solúveis, alta capacidade de tamponamento, conforme discutido para PB.

Não ocorreu diferença para NIDN entre os tratamentos sem aditivo e com adição de aditivo comercial. Este resultado coadunase com os de Berto e Mühlback (1997), que também não detectaram efeito do aditivo enzimo-bacteriano sobre os teores de NIDN da silagem de aveia.

O uso da polpa cítrica aumentou o teor de NIDA de 5,58 para 6,15 e 6,78\% em relação a silagem não tratada, de forma semelhante também ocorreu efeito para o tratamento com óxido de cálcio 7,17\% (tabela II). Estes resultados estariam relacionados aos discutidos anteriormente para NIDN, haja vista que a excessiva produção de calor pode comprometer a integridade e disponibilidade da fração nitrogenada. Acima de $49^{\circ} \mathrm{C}$, a proteína pode reagir com os carboidratos da planta, e passar a fazer parte da FDA tornando-se indigestível (reação de Maillard).

A adição dos aditivos nas silagens promoveu decréscimo nos valores de celulose (tabela II) das silagens $(p<0,05)$. A celulose sofre pouco ou quase nenhum efeito durante a fermentação, entretanto, segundo Reis e Jobim (2001) os resultados de pesquisas demonstram que em silagens de gramíneas uma pequena fração (menos de $5 \%$ ) da celulose pode sofrer degradação pelo efeito das enzimas.

A lignina (tabela II) constitui um polímero fenólico que se associa aos carboidratos estruturais, celulose e hemicelulose, durante o processo de formação da parede celular, alterando significativamente a digestibilidade destes carboidratos das forragens (Van Soest e Wine, 1968). Foi constatado

Tabela II. Teores médios (\%) de fibra em detergente neutro (FDN), fibra em detergente ácido (FDA), nitrogênio insolúvel no detergente neutro (NIDN/NT), nitrogênio insolúvel no detergente ácido (NIDA/NT) em função do nitrogênio total (NT), celulose (CEL), lignina (LIG) e digestibilidade in vitro da matéria seca (DIVMS) das silagens de capim Pennisetum hybridum cv. Paraíso. (Contents (\%) of FDN, FDA, NIDN/NT, NIDA/NT, as function of total nitrogen (NT) and DIVMS digestibility of Pennisetum hybridum cv. Paraíso silage).

\begin{tabular}{lccccccc}
\hline Tratamentos & FDN & FDA & NIDN/NT & NIDA/NT & CEL & LIG & DIVMS \\
\hline Silagem de capim paraíso & $67,21^{\mathrm{a}}$ & $45,38^{\mathrm{a}}$ & $6,51^{\mathrm{c}}$ & $5,58^{\mathrm{c}}$ & $38,21^{\mathrm{a}}$ & $4,95^{\mathrm{ab}}$ & $58,61^{\mathrm{d}}$ \\
+ 5\% de polpa cítrica & $58,32^{\mathrm{c}}$ & $41,93^{\mathrm{b}}$ & $8,15^{\mathrm{b}}$ & $6,15^{\mathrm{b}}$ & $35,61^{\mathrm{d}}$ & $4,41^{\mathrm{c}}$ & $64,98^{\mathrm{b}}$ \\
+ 10\% de polpa cítrica & $56,70^{\mathrm{c}}$ & $40,48^{\mathrm{c}}$ & $10,12^{\mathrm{a}}$ & $6,78^{\mathrm{a}}$ & $34,41^{\mathrm{e}}$ & $4,62^{\mathrm{bc}}$ & $68,06^{\mathrm{a}}$ \\
+ CaO & $62,96^{\mathrm{b}}$ & $44,86^{\mathrm{a}}$ & $11,01^{\mathrm{a}}$ & $7,17^{\mathrm{a}}$ & $36,89^{\mathrm{b}}$ & $5,26^{\mathrm{a}}$ & $54,99^{\mathrm{e}}$ \\
+ aditivo comercial & $66,14^{\mathrm{a}}$ & $42,48^{\mathrm{b}}$ & $6,27^{\mathrm{c}}$ & $5,27^{\mathrm{c}}$ & $36,19^{\mathrm{c}}$ & $4,47^{\mathrm{c}}$ & $62,24^{\mathrm{c}}$
\end{tabular}

Médias seguidas de mesma letra na coluna não diferem entre si pelo teste de Tukey a $5 \%$.

Archivos de zootecnia vol. 58, núm. 222, p. 190. 
efeito significativo $(\mathrm{p}<0,05)$ da adição de polpa cítrica e do aditivo comercial em relação aos teores de lignina das silagens que decresceram em relação ao tratamento sem aditivo. Estes resultados obtidos quando comparados aos de Bernardes (2003) mostram a mesma tendência.

A adição de polpa cítrica promoveu aumento nos valores de digestibilidade in vitro da matéria seca (DIVMS), como também a silagem que recebeu aditivo comercial $(\mathrm{p}<0,05)$. Esta maior digestibilidade relaciona-se aos menores teores de FDN, FDA, celulose e lignina, fato este verificado por Bernardes (2003), em silagem de capim marandu acrescida de polpa cítrica. Evidenciamos ainda que o valor verificado para a silagem com aditivo comercial $(62,24 \%)$, neste estudo foi maior que o obtido por Bergamaschine et al. (2006) e Coan et al. (2005) que foi de 60,23 e 54,5\% respectivamente para silagem de capim tanzânia com 60 dias de crescimento.

$\mathrm{O}$ valor de $\mathrm{pH}, \mathrm{N}$-amoniacal e ácidos orgânicos, são empregados na avaliação da qualidade da silagem e, geralmente, constituem indicativos das mudanças ocorridas durante a fermentação (tabela III).

Em relação ao $\mathrm{pH}$, somente o tratamento com óxido de cálcio obteve valores acima de 4,2 mencionado por Breirem e Ulvesli (1960) para silagem de boa qualidade. O baixo teor de MS associado aos altos teores proteína neste estudo e o efeito tamponante do óxido de cálcio, contribuíram para esse efeito. Entretanto com relação aos outros tratamentos o tamanho das partículas e a compactação adequada promoveram condições para que o $\mathrm{pH}$ das silagens fosse adequado ao processo de ensilagem o que concorda com Neumann et al. (2007).

Os valores de nitrogênio amoniacal em função do nitrogênio total $\left(\mathrm{NH}_{3} / \mathrm{NT}\right)$ foram muito altos para a silagem com óxido de cálcio e elevado para a silagem sem aditivo, indicando que houve forte desdobramento de aminoácidos, caracterizando-as como sendo de baixa qualidade. Por outro lado, os tratamentos com 5\% de polpa cítrica ou com aditivo comercial mostraram valores bem próximos aos $10 \%$ de $\mathrm{NH}_{3} / \mathrm{NT}$, indicados por Ferreira (2001) como adequados para as silagens de milho e sorgo.

Entretanto somente mediante o emprego de $10 \%$ de polpa cítrica resultou em valores $\mathrm{de}_{3} / \mathrm{NT}$ de $8,95 \%$, considerado adequado e efetivo para prevenir a proteólise.

$\mathrm{O}$ aditivo comercial utilizado alterou o perfil da fermentação no silo, proporcionando silagem com $\mathrm{pH}$ e teores de $\mathrm{NH}_{3} / \mathrm{NT}$, inferiores aos da silagem sem nenhum tratamento.

Tabela III. Valores de $\mathrm{pH}$, percentual de nitrogênio amoniacal em relação ao nitrogênio total $\left(\mathrm{NH}_{3} / \mathrm{NT}\right)$, ácido lático (LAT), ácido acético (ACE), ácido butírico (BUT) e ácido propiônico (PROP) das silagens de capim Pennisetum hybridum $c v$. Paraíso. (Values of $\mathrm{pH}$, percentage of ammonia nitrogen $\left(\mathrm{NH}_{3} / \mathrm{NT}\right)$ as function of total nitrogen (NT), lactic acid (LAT), acetic acid (ACE), butiric acid (BUT) and propionic acid (PROP) of Pennisetum hybridum cv. Paraíso silage).

\begin{tabular}{lrrrrrr}
\hline Tratamentos & $\mathrm{pH}$ & $\mathrm{NH}_{3} / \mathrm{NT}$ & $\mathrm{LAT}$ & $\mathrm{ACE}$ & $\mathrm{BUT}$ & PROP \\
\hline Silagem de capim paraíso & $3,36^{\mathrm{b}}$ & $14,01^{\mathrm{b}}$ & $8,97^{\mathrm{c}}$ & $1,46^{\mathrm{a}}$ & $0,02^{\mathrm{b}}$ & $0,02^{\mathrm{b}}$ \\
+ $5 \%$ de polpa cítrica & $3,15^{\mathrm{c}}$ & $10,83^{\mathrm{c}}$ & $9,15^{\mathrm{c}}$ & $1,52^{\mathrm{a}}$ & $0,01^{\mathrm{b}}$ & $0,02^{\mathrm{b}}$ \\
+ $10 \%$ de polpa cítrica & $3,18^{\mathrm{c}}$ & $8,95^{\mathrm{d}}$ & $12,15^{\mathrm{a}}$ & $1,44^{\mathrm{a}}$ & $0,01^{\mathrm{b}}$ & $0,02^{\mathrm{b}}$ \\
+ CaO & $5,30^{\mathrm{a}}$ & $55,79^{\mathrm{a}}$ & $0,74^{\mathrm{d}}$ & $0,83^{\mathrm{b}}$ & $4,79^{\mathrm{a}}$ & $1,38^{\mathrm{a}}$ \\
+ aditivo comercial & $3,15^{\mathrm{c}}$ & $10,42^{\mathrm{c}}$ & $10,40^{\mathrm{b}}$ & $0,05^{\mathrm{c}}$ & $0,18^{\mathrm{b}}$ & $0,04^{\mathrm{b}}$ \\
\hline
\end{tabular}

Médias seguidas de mesma letra na coluna não diferem entre si pelo teste de Tukey a $5 \%$. 


\section{FERRARI JUNIOR, PAULINO, POSSENTI E LUCENAS}

Todos os ácidos orgânicos que aparecem nas silagens (lático, acético butírico, propiônico e outros), obviamente contribuem para a acidez total da massa ensilada. Entretanto, o ácido lático apresenta maior constante de dissociação e por isso, é o maior responsável pela redução no $\mathrm{pH}$ da massa ensilada.

Entre os tratamentos estudados, somente a silagem adicionada de óxido de cálcio apresentou valores inferiores aos indicados por Catchpoole e Henzell (1971) que variam de 3 a $13 \%$ de ácido lático para silagens de forrageiras tropicais.

Quanto à qualidade das silagens medida em termos de porcentagem de ácido acético, pode-se afirmar que todas apresentaram valores inferiores aos verificados por Andrade e Melotti (2003), principalmente para o tratamento com adição de aditivo comercial, indicando que as silagens inoculadas com adequada quantidade de bactérias produtoras de ácido lático apresentarão $\mathrm{pH}$ final baixo, menores conteúdos de ácido acético enitrogênio amoniacal,maior conteúdo de ácido lático, quando comparadas a silagem sem aditivos.

A presença de ácido butírico na massa ensilada é sempre acompanhada de mudanças na qualidade do produto. $\mathrm{O}$ efeito

\section{BIBLIOGRAFIA}

A.O.A.C. 1995. Official methods of analysis. Association of Official Analytical Chemists. Washington D.C.

Andrade, S.J.T e L. Melotti. 2003. Inoculantes bacterianos na ensilagem do capim-elefante (Pennisetum purpurem, Schum). Braz. J. Vet. Res. Anim. Sci., 40: 219-223.

Balieiro Neto, G. e M.L.P. Lima. 2006. Silagem de cana-de-açúcar: quando e como pode ser viável. Em: Encontro Técnico sobre Conservação de Forragens (Silagens), 2006. Nova Odessa. Anais... Instituto de Zootecnia. Nova Odessa.

Bergamaschine, A.F., M. Passipieri e W.V. Veriano Filho. 2006. Qualidade e valor nutritivo de silagens prejudicial das bactérias produtoras de ácido butírico é o desdobramento de proteínas. Segundo Ferreira (2001) silagens com até $0,1 \%$ de ácido butírico, poderiam ser consideradas adequadas. Neste sentido, podemos inferir que o tratamento com óxido de cálcio e aditivo comercial foram inadequados no controle deste tipo de fermentação.

De forma semelhante, somente o tratamento com óxido de cálcio mostrou-se diferente $(\mathrm{p}<0,05)$ dos demais para ácido propiônico.

\section{CONCLUSÕES}

A silagem de capim Paraíso sem aditivos pode ser considerada como sendo de qualidade razoável.

A adição de polpa cítrica é recomendável, pois foi eficiente em aumentar o teor de MS do material ensilado resultando em silagens com padrões fermentativos mais adequados.

O óxido de cálcio não trouxe benefícios à silagem não sendo indicado para capins com baixos teores de MS.

$\mathrm{O}$ aditivo comercial (Silomax) proporcionou um bom padrão de fermentação da silagem, porém seus efeitos foram menores que os obtidos com o uso da polpa cítrica.

de capim-marandu (B. brizantha cv. Marandu) produzidas com aditivos ou forragem emurchecida. Rev. Bras. Zootecn., 35: 1454-1462.

Bernardes, T.F. 2003. Características fermentativas, microbiológicas e químicas do capimmarandu (Brachiaria brizantha (Hochst ex. a Rich) Stapf cv. Marandu) ensilado com polpa cítrica peletizada. Dissertação de Mestrado. Faculdade de Ciências Agrárias e Veterinárias do Campus de Jaboticabal. UNESP. São Paulo. Brasil. $82 \mathrm{p}$

Berto, J.L. e P.R.F. Mühlbach. 1997. Silagem de aveia preta no estádio vegetativo, submetida à ação de inoculantes e ao efeito do emurchecimento. Rev. Bras. Zootecn., 26: 651-658.

Archivos de zootecnia vol. 58, núm. 222, p. 192. 


\section{ADITIVOS EM SILAGEM DE CAPIM ELEFANTE (PENNISETUM HYBRIDUM) PARAÍSO}

Breirem, K. and O. Ulvesli. 1960. Ensiling methods. Herb. Abstr., 30: 1-8.

Catchpoole, V.R. and E.F. Henzell. 1971. Silage and silage-making from from tropical hebage species. Herb. Abstr., 41: 213-221.

Coan, R.M., P.F. Vieira, R.N. Silveira, R.A. Reis, E.B. Malheiros e M.S. Pedreira. 2005. Inoculante enzimático-bacteriano, composição química $e$ parâmetros fermentativos das silagens dos capins Tanzânia e Mombaça. Rev. Bras. Zootecn., 34: 416-424.

Erwin, E.S, G.J. Marco and E.M. Emery. 1961. Volatile fatty acid analyses of blood and rumen fluid by gas chromatography. J. Dairy Sci., 44: 1768-1771.

Evangelista, A.R., J.A. Lima e G.R. Siqueira. 2001. Aditivos na ensilagem de coast-cross (Cynodon dactylon (L.) Pers. 1. Farelo de trigo e polpa cítrica. Em: Reunião Anual da Sociedade Brasileira de Zootecnia, 38. 2001. Piracicaba. Anais... SBZ. Piracicaba. p. 71.

Faria, D.J.G., R. Garcia e O.G. Pereira. 2007. Composição químico-bromatológica da silagem de capim elefante com níveis de descarte de café. Rev. Bras. Zootecn., 36: 301-308.

Fenner, H. 1965. Method for determinning total volatile bases in rumen fluid by steam distillation. J. Dairy Sci., 48: 249-251.

Ferrari Júnior, E. e W. Lavezzo. 2001. Qualidade da silagem de capim elefante (Pennisetum purpureum Schum) emurchecido ou acrescido de farelo de mandioca. Rev. Soc. Bras. Zootecn., 30: 1424-1431.

Ferreira, J.J. 2001. Estágio de maturação ideal para ensilagem do milho e sorgo. Em: Cruz, J.C., I. A. Pereira Filho (Eds.). Produção e utilização de silagem de milho e sorgo. Embrapa milho e sorgo. Sete Lagoas. MG. p. 405-428.

Figueiredo, M.P., S.A. Sousa, G.R. Moreira, L.F. Sousa e J.Q. Ferreira. 2004. Determinação do teor de matéria seca do capim elefante (Pennisetum purpureum Schum), em três estádios de maturidade fisiológica, pelo forno de microondas. Magistra, 16: 113-119.

Goering, H.K. and P.J. Van Soest.1970. Forage fiber analysis. (apparatus, reagents, procedures, and some applications). Agric. Handbook. ARS, USDA. Washington, DC. 379 p.

Haigh, P.M. 1999. Effluent production from grass silages treated with additives and made in large- scale bunker silos. Grass Forage Sci., 54: 208218.

Keplin, L. 2006. Produção de silagem de qualidade e uso de inoculantes. Em: Encontro Técnico sobre Conservação de Forragens (Silagens), 2006. Nova Odessa. Anais... Instituto de Zootecnia. Nova Odessa.

Neumann, M.,P.R.F. Mühlbach, J.L. Nörnberg, P.R. Ost, J. Restle, I. E. Sandini e M.A. Romano . 2007. Características da fermentação da silagem obtida em diferentes tipos de silos sob efeito do tamanho de partícula e da altura de colheita das plantas de milho. Cienc. Rural, 37: 32-39.

Oliveira, A.C., A.J.V. Pires, H.C. Oliveira, N.M.S. Patês, N.C. Foncêca, G.G.P Carvalho e A.B. Oliveira. 2007. Composição nitrogenada de silagens de gramíneas tropicais tratadas com uréia. Arch. Zootec., 56: 15-21.

Oshima, M. and P.A. McDonald. 1978. A review of the changes in nitrogenous compound of herbage during ensilage. J. Sci. Food Agric., 29: 497-502.

Patrizi , W.L., C.R.F. Madruga Júnior, T.P. Minetto, E. Nogueira e M.G. Morais. 2004. Efeito de aditivos biológicos comerciais na silagem de capim Elefante (Pennisetum purpureum Schum). Arq. Bras. Med. Vet. Zoo., 56: 392-397.

Reis, R.A., T.F. Bernardes e R. Amaral. 2004. Teores de compostos nitrogenados do capim Marandu (Brachiaria brizantha, cv. Marandu) ensilado com polpa cítrica peletizada. Em: Reunião da Sociedade Brasileira de Zootecnia, 40. 2004. Campo Grande, MS. Anais... Forragicultura. Sociedade Brasileira de Zootecnia. Campo Grande.

Reis, R.A. e C.C. Jobim. 2001. Perfil da fração de carboidratos da planta e adequação de aditivos no processo de ensilagem. Em: Workshop sobre milho para silagem, 2. Piracicaba, 2001. Anais... FEALQ. Piracicaba. p. 27-52.

SAS. 1998. User's guide: Statistcs. $7^{\text {th }}$ ed. SAS Institute Inc. Cary, NC.

Schank, S.C., C.R. Staples, K.E. Thompson and D. Bates. 1992. Forage and silage production from seeded pearl millet-dwarf elefantgrass hybrids. In: Florida Dairy Production Conference 29 ${ }^{\text {th }}$, Gainesville, Proceedings ... University of Florida. Gainesville. p. 133-138.

Silva, D.J. e C.A. Queiroz. 2002. Análise de alimentos (Métodos químicos e biológicos). Ed. UFV, 


\section{FERRARI JUNIOR, PAULINO, POSSENTI E LUCENAS}

Universidade Federal de Viçosa. Viçosa. $235 \mathrm{p}$ Silveira, A.C., W. Lavezzo e H. Tosi. 1979. Avaliação química das silagens de capim elefante (Pennisetum purpureum, Schum.) submetidas a diferentes tratamentos. Rev. Bras. Zootecn., 8: 287-300.

Tilley, J.M.A. and R.A. Terry. 1963. A two stage technique for the in vitro digestion of forage crops. J. Br. Grass/d. Soc., 18: 104-111.
Valadares Filho, S.C., V.R. Rocha Júnior e E.R. Cappelle. 2002. Tabelas brasileiras de composição de alimentos para bovinos. Universidade Federal de Viçosa, UFV. Viçosa, MG, Brasil. 297 p.

Van Soest, P.J. and R.H. Wine. 1968. Determination of lignina and celulose in acid detergent fiber with permanganate. J. Assoc. Agric. Chem., 51: $780-85$. 